\title{
Delivering Key Graduate Attributes via Teams Working in Virtual Space
}

\author{
http://dx.doi.org/ijet.v6i3.1657 \\ Lyn Brodie \\ University of Southern Queensland, Toowoomba, Australia
}

\begin{abstract}
Transferable skills are gaining an increasing emphasis in engineering education. The skills of teamwork, communication, self directed learning and problem solving feature in most of the accrediting agencies criteria. This paper is a case study of a course which uses Problem Based Learning method to deliver key transferable skills to engineering students studying via distance education The students use a range of communication systems including a Learning Management System which offers synchronous and asynchronous communications to work in a team where there is no face to face contact between either the team members or with the supervising academic. The teams solve open ended, contextualised engineering problems. These teams form a learning community which scaffolds individual and team learning goals. Results from a longitudinal study show that students significantly increase their teamwork, communication, problem solving and self directed learning skills. These are key graduate attributes now required by professional accreditation bodies. In addition specific theoretical and technical skills and knowledge are learnt and applied to new problems.
\end{abstract}

Index Terms-virtual teams, Problem Based Learning, graduate attributes

\section{INTRODUCTION}

The University of Southern Queensland (USQ) is a small Australian regional university. It has gained an international reputation for distance education with approximately $75 \%$ of students studying by traditional distance education or in an 'online' mode. The University has 5 faculties - Business, Science, Arts, Education and Engineering and Surveying.

The Faculty of Engineering and Surveying (FOES) offers postgraduate courses and four articulated undergraduate programs - Associate Degree ( $\mathrm{AD}$ - 2 years), Bachelor of Technology (BTech - 3 years), Bachelor of Engineering or Bachelor of Spatial Science (BEng - 4 years) and double degree programs (5 years) e.g. Bachelor of Engineering and Business or Bachelor of Engineering and Science. These undergraduate programs can be based in one of nine major areas of study - agricultural, electrical and electronic, mechanical, civil, spatial science (surveying), Geographic Information Systems (GIS), mechatronic, computer systems, and environmental.

USQ also offers multiple entry pathways to its university programs, as shown in Figure 1[1]. The flexible entry, articulation and high quality distance education programs encourages a diverse enrolment. Whilst the Australian average for enrolments other than full time on campus is approximately 27\% [2], USQ has approximately $80 \%$ of students studying via distance education [3]. These stu-

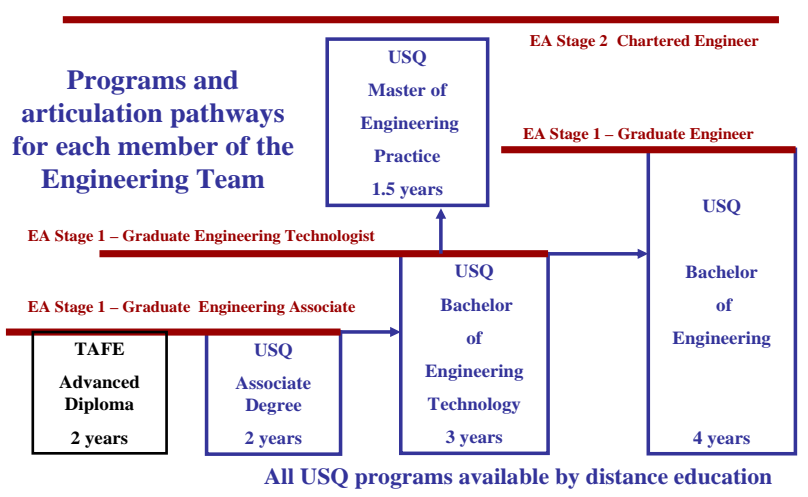

Figure 1. Articulation of Faculty programs [4]

dents are largely mature age, working in the engineering and surveying industry and have a varying set of preuniversity learning and work experiences.

Usually a diverse student cohort is seen as a disadvantage or a problem for academics. At what level is lecture material pitched? how can you best maintain student interest and motivation? and how can progression and retention rates be maintained or improved? It is demonstrated in this paper that team based Problem Based Learning (PBL), where peer mentoring and assistance is encouraged and rewarded, is one solution. This allows the course pedagogy to work with, and use to advantage, prior knowledge of the student cohort.

\section{BACKGROUND}

In 2001, FoES introduced a problem-based learning (PBL) approach for four courses to ensure that graduates developed problem-solving skills and the ability to work effectively in multidisciplinary teams. These PBL courses replaced traditionally taught courses. The strand was designed to sequentially and progressively strengthen these skills and knowledge as well as key technical knowledge. The scaffolding and articulation of the courses is shown in Table 1.

The student cohort is diverse ranging from school leavers to mature age students entering tertiary education for the first time, often without normal prerequisite studies in math and physics. These older students do however bring significant life and relevant industry experience to the teams. This student diversity is a significant resource for the teams and mentoring and peer assistance is part of the assessment strategy. The recognition of prior knowledge and learning and the ability to set individual learning goals has increased the progression and retention rates and the team work has also encouraged a social network which has not been previously available to distance students. 
TABLE I.

PAPERS PBL STRAND OF COURSES

\begin{tabular}{|l|l|l|}
\hline Course & Student cohort - all majors & $\begin{array}{l}\text { Team } \\
\text { Size }\end{array}$ \\
\hline Research Project & $\begin{array}{l}\text { Bachelor of Engineering, Bache- } \\
\text { lor of Spatial Sciences }\end{array}$ & $\begin{array}{l}1 \text { (indi- } \\
\text { vidual) }\end{array}$ \\
\hline $\begin{array}{l}\text { Engineering } \\
\text { Problem Solving } \\
4\end{array}$ & Bachelor of Engineering & $\begin{array}{l}3 \text { to } 4 \\
\text { students }\end{array}$ \\
\hline $\begin{array}{l}\text { Engineering } \\
\text { Problem Solving }\end{array}$ & Bachelor of Engineering & $\begin{array}{l}3 \text { to } 5 \\
\text { students }\end{array}$ \\
\hline $\begin{array}{l}\text { Engineering } \\
2\end{array}$ & $\begin{array}{l}\text { Broblem Solving } \\
\text { lor of Spatial Sciences, Bachelor } \\
\text { of Technology, Associate Degree }\end{array}$ & $\begin{array}{l}5 \text { to 7 } \\
\text { students }\end{array}$ \\
\hline $\begin{array}{l}\text { Engineering } \\
\text { Problem Solving } \\
1\end{array}$ & $\begin{array}{l}\text { Bachelor of Engineering, Bache- } \\
\text { lor of Spatial Sciences, Bachelor } \\
\text { of Technology, Associate Degree }\end{array}$ & $\begin{array}{l}6 \text { to } 8 \\
\text { students }\end{array}$ \\
\hline
\end{tabular}

In these PBL courses, students learn to work together in teams to solve open-ended problems [5]. They share knowledge and resources, mentor and formulate a formal problem solving and team work process which can be used in other problems and courses. Throughout the first PBL course the emphasis is on team process and individual advancement with a reduces emphasis on 'the answer or report'. This encourages team members to take on unfamiliar tasks and tackle individual learning goals rather than focusing on producing a perfect team report. Only an introductory lecture is given to oncampus students (online formats are provided for distance students). No other lectures are given and only minimal technical resources are provided with each team supported to find resources inline with the team and individual learning goals which are set as part of the first assessment task. This is inline with the original form of PBL which starts the learning process with a problem and support, such as lectures, may be given, but only as an additional information for the problem [6].

\section{PROBLEM BASED LEARNING}

Traditional education tends to approach learning by presenting concepts in identifiable blocks, in a linear, or at least logical, sequence. Implicit in this approach is the belief that learning amounts to acquiring a set of 'rules' which much be practiced separately to be learnt and only then can be applied. The 'practice' relies on applying the rules to similar situations and with enough practice comes understanding and then the knowledge and rules can be applied to new or novel situations [7]. However, educational research has demonstrated that a "student is not an empty vessel waiting to be filled with new knowledge" and many common teaching practices such as lectures result in surface learning [8].

PBL is based on the principles of adult education and cognitive psychology [9, 10]. Barrows [11] describes a cycle of three phases of PBL. Firstly students encounter a problem, as opposed to a fact or theory. Then the problem is discussed and deconstructed usually in a small group setting. The problem and discussion motivates the student to undertake self directed study and research framed by prior knowledge, understanding and gaps within these areas. Lastly new knowledge is applied and learning summarised by reflection.

Given these advantages, PBL has now been adopted by many disciplines and is practiced very differently in dif- ferent institutions [7, 12-16]. However, in implementing PBL a failure to understand the fundamentals of the method, a failure to embrace the change at all levels of the institution and a failure to adequately resource the course/program including staff training will lead to a failure to achieve anticipated learning outcomes[17]. All these issues in addition to clear learning objectives set within the engineering education framework must be addressed. PBL can deliver much needed reform to the curriculum and teaching process and does go far in addressing the future needs of the profession.

Engineering is a creative, team-based, problem solving profession which sits at the interface of the sciences and society, and is recognised as such by accrediting agencies such as Engineers Australia and ABET in their program accreditation documents [18, 19]. Students need the basic tools of engineering science and their applications to make informed decisions, validate, and actually solve problems, but equally fundamental is the need to do this in a team environment meeting ethical, business and organisational needs.

Organisational needs are changing. Globalisation, technology, flexible work practices and a shrinking skilled and experienced work force in the Western world are changing how many organisations operate and this trend is likely to continue. Many organisations remain structured around traditional face-to-face teams but Arnison and Miller [20] argue that, increasingly, these conventional face-to-face teams may increase productivity by utilising technology for communication, file sharing and sharing work across offices, time zones and even other organisations.

These changes have been noted as impacting on engineers and engineering education for example by Thorben \& Schwesig [21], National Academy of Engineering [22, 23] and Jamieson 23 who all predict the need for desirable engineering graduate attributes to be expanded to include:

- Working globally in a multicultural environment;

- Working in interdisciplinary and multi skilled teams;

- Sharing of work tasks on a global and around the clock basis;

- Working with digital communication tools and

- Working in a virtual environment.

It follows that universities need to equip students with skills that help them cope with evolving technology and global demands of the profession. This leads to engineers working not only in face-to-face teams, but learning and applying appropriate skills and techniques to virtual teams.

\section{COURSE OUTLINE}

While delivery of PBL to an on-campus cohort is widely used around the world, there was scant data related to distance delivery. Moving to a fully virtual environment considerable effort was need by the teaching team to establish a learning community in virtual space for the students to remotely engage with their team, their facilitator and other students in the course. However, even with this forewarning, the effort required in establishing a true 'team' for the students was underestimated for the distance students who have no opportunity for face-to-face communication or contact. In addition the distance student typically has no history of sourcing their own study mate- 


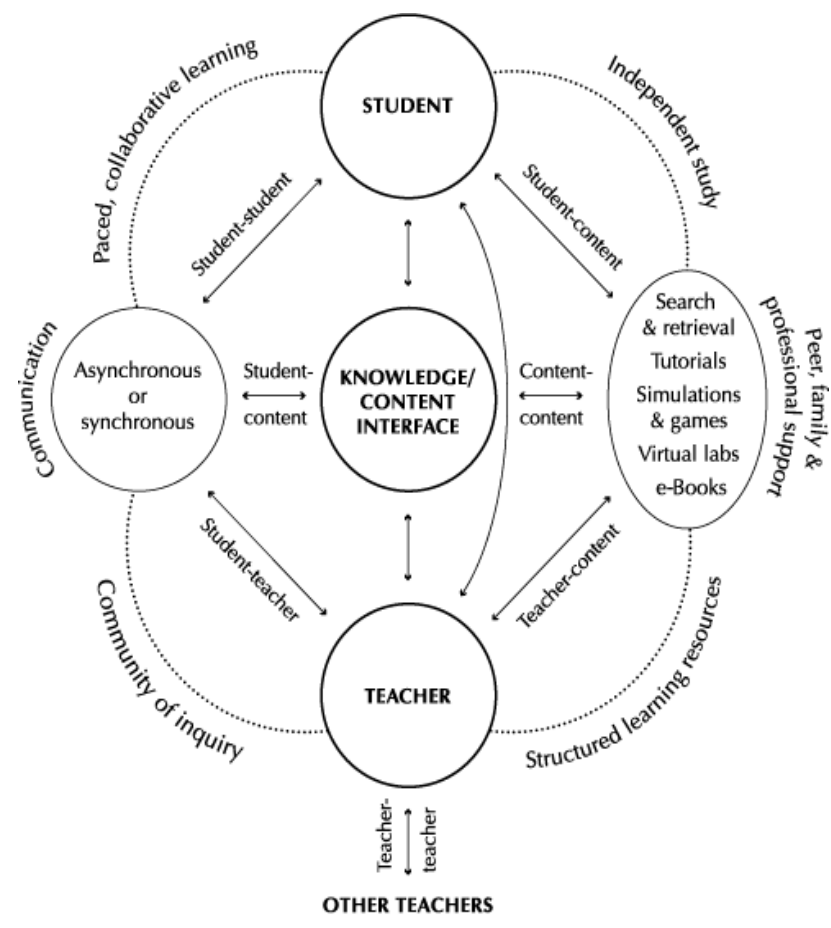

Figure 2. A model for online teaching and learning [24]

rial and resources. Study materials are usually, if not always, printed material and the entire course study resource - content, tutorial problems, assessment items and sample examinations, are provided to the student.

Reference [24] (Figure 1) provided a model as a foundation for online PBL. The model provides a framework for the interactions between multiple students and the academic facilitator via synchronous and asynchronous communication. Technologies can deliver resources and content required to support individual student learning in a learning community and teamwork in a virtual environment [25].

In the first course of the strand, students are allocated to a team of eight. Whilst this is at the upper limit that the current literature advises, the larger initial team size was able to cater for students who drop the course and not affect the viability of the team. This meant that teams did not have to spend extra time and effort reforming during semester. Initially the allocation of team members was such to simply ensure that each team had a mixture of Associate Degree (AD, 2 year program), Bachelor of Technology (BTech, 3 year program) and Bachelor of Engineering (BEng , 4 year program) students of all majors, as numbers allowed thus giving the widest chance at diversity a mix of prior knowledge and skills.

This paper concentrates on the first of these PBL courses (ENG1101), which is compulsory for all students in the faculty. The main objectives of this course are to develop the fundamental skills needed by students to participate effectively in multi-disciplinary teams, develop communication skills, and to expose students to a wide range of problem-solving tools.

The data spans the years 2005 to 2008 . Whilst this longitudinal study is ongoing, the focus of new and current investigations is to establish the link between student learning and facilitator i.e. what impact does different facilitator styles and strategies have on both student learn- ing, student motivation and student attitudes to the PBL courses. Initial evaluation of facilitator training and its impact on students has been reported by Brodie and Jolly [26]. This investigation is continuing; however, there is a strong link between facilitator (style and method) and student attitudes. This is not reflected or discussed in these results.

\section{Evaluation Methodology}

The success of the course and student learning has been evaluated by:

- Student demographics.

- Anonymous evaluation surveys. These cover student perceptions of 'the course' including resources, their 'facilitator' and their 'learning'.

- Analysis of individual reflective portfolios

- Use of the LMS and wiki pages, including number and frequency of postings, hours of student interaction and number of edits to the wiki pages.

\section{- Student focus groups}

Initial evaluations and monitoring of the course where conducted from 2001 to 2004 and this resulted in incremental and continuous changes to the course including assessment strategies [27, 28] and facilitator training [26, 29]. Changes to the course and assessment were complete by semester 12005 and the second phase of data collection began. Data was collected until the end of the first semester 2008, covering 11 offers of the course. Data for semester 2, 2008 was not used in the analysis as problems with the learning management system prevented the surveys being available to all students and hence there was a very small response, well below the average of previous semesters.

Survey responses from 820 of the 1377 students (response rate $=59.5 \%$ ) enrolled over the time frame were collected. Responses were on a five point Likert scale with responses of Strong Agree (SA), Agree (A), Neutral (N), Disagree (D) and Strongly Disagree (SD), NA (not answered). The student perception data were validated by analysis of open ended responses to survey questions, discussion forums and student postings and student reflective portfolios. Portfolios were chosen randomly from the student cohort to match the profile of program of enrolment.

\section{STUDENT DEMOGRAPHICS}

Figures 2, 3 and 4 detail the profile of the student cohort. From 2005 to 2008 there was a significant growth in enrolments into the Associate Degree program (Figure 2). Many of these students will in time articulate into either the Bachelor of Technology or the Bachelor of Engineering, but in beginning university they do not have the sufficient prerequisite studies especially mathematics to enroll in the four year Bachelor program. The majority of the $\mathrm{AD}$ enrolments are into the civil major (see Figure 3).

The age profile of the students is shown in Figure 4. The data from the survey shows the majority of students are in the 18 to 24 years age bracket. Further interrogation of enrolments shows that only $13 \%$ of the students come directly to university from school. Thus the vast majority of students have work experience of some form before they enter university. 


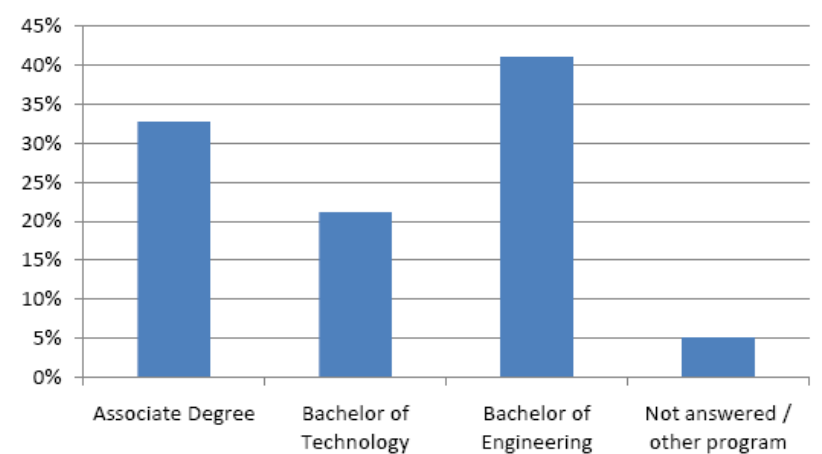

Figure 3. Program of enrolments

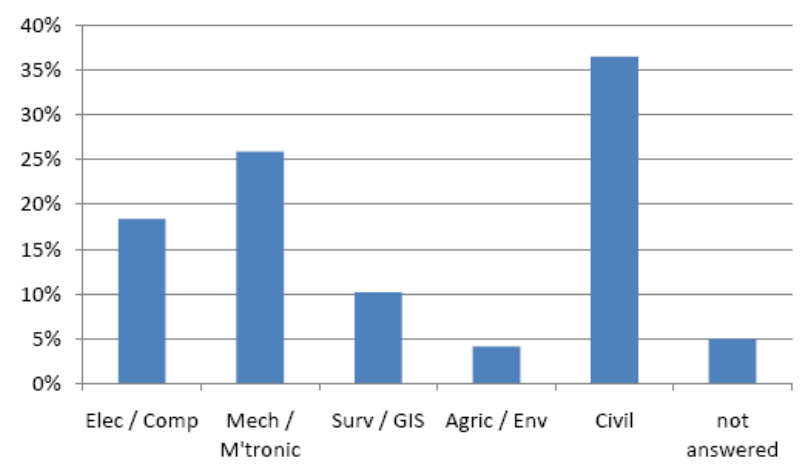

Figure 4. Distribution of discipline majors

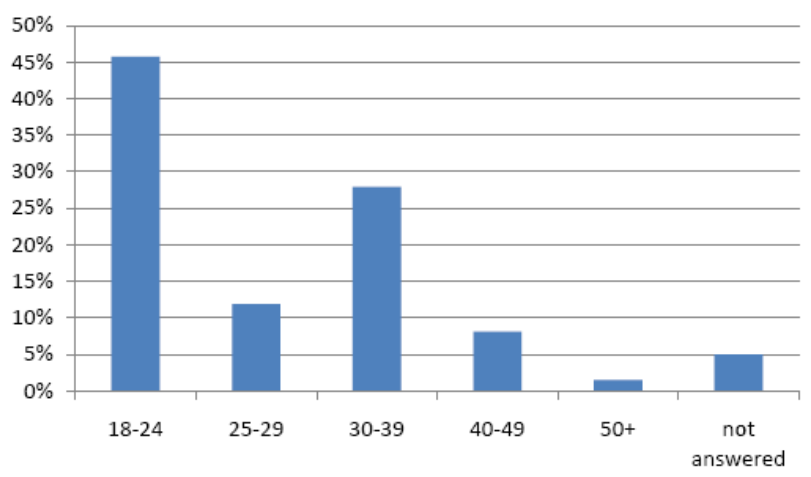

Figure 5. Age profile of students

The survey results, validated by thematic analysis of student and staff reflective portfolios, are comprehensive documents covering many aspects of the course including administration, resources, assistance provided by facilitators and individual student learning. The investigation focused on establishing whether the key graduate attributes of problem solving, teamwork, communication skills and lifelong and self directed learning could be successfully delivered using problem based learning with students working in virtual teams.

Considering these four main areas, there was no significant difference between the on-campus and distance students for ability to learn independently and enhancing communication skills as shown in Table II. Statistically, there was a small difference between on-campus and distance students in their responses for problem solving skills and teamwork questions. However, the trends in the data are clear as evidence by the data shown in Table III.

The slight increase in distance students who do not believe their teamwork skills were enhanced by the course
TABLE II.

SIGNIFICANT DIFFERENCE IN STUDENT RESPONSES BETWEEN ONCAMPUS AND DISTANCE STUDENTS

\begin{tabular}{|c|c|c|c|}
\hline $\begin{array}{r}\text { study mode } \\
\text { ple Cho }\end{array}$ & $\begin{array}{l}\text { Multi- } \\
\text { сe) }\end{array}$ & $\mathbf{N}$ & Mean Rank \\
\hline $\begin{array}{l}\text { ability to learn inde- } \\
\text { pendently enhanced dimension1 } \\
\text { (Multiple Choice) }\end{array}$ & $\begin{array}{c}1 \\
2 \\
\text { Total }\end{array}$ & $\begin{array}{l}593 \\
224 \\
817\end{array}$ & $\begin{array}{l}416.17 \\
390.03\end{array}$ \\
\hline $\begin{array}{l}\text { communication skills } \\
\text { were enhanced (Multiple dimension1 } \\
\text { Choice) }\end{array}$ & $\begin{array}{c}1 \\
2 \\
\text { Total } \\
\end{array}$ & $\begin{array}{l}594 \\
224 \\
818\end{array}$ & $\begin{array}{l}401.23 \\
431.43\end{array}$ \\
\hline $\begin{array}{l}\text { problem solving skills } \\
\text { were enhanced (Multiple dimension1 } \\
\text { Choice) }\end{array}$ & $\begin{array}{c}1 \\
2 \\
\text { Total }\end{array}$ & $\begin{array}{l}594 \\
224 \\
818\end{array}$ & $\begin{array}{l}400.61 \\
433.07\end{array}$ \\
\hline $\begin{array}{lc}\text { teamwork } & \text { skills were } \\
\text { enhanced } & \text { (Multiple dimension1 } \\
\text { Choice) } & \\
\end{array}$ & $\begin{array}{c}1 \\
2 \\
\text { Total }\end{array}$ & $\begin{array}{l}594 \\
224 \\
818\end{array}$ & $\begin{array}{l}400.45 \\
433.51\end{array}$ \\
\hline
\end{tabular}

\begin{tabular}{|c|c|c|c|c|}
\hline \multicolumn{5}{|c|}{ Test Statistics $^{a, b}$} \\
\hline & $\begin{array}{l}\text { ability to } \\
\text { learn inde- } \\
\text { pendently } \\
\text { enhanced } \\
\text { (Multiple } \\
\text { Choice) }\end{array}$ & \begin{tabular}{|c|} 
\\
communication \\
skills were en- \\
hanced (Multiple \\
Choice)
\end{tabular} & \begin{tabular}{|c|} 
problem \\
solving \\
skills \\
were \\
enhanced \\
(Multiple \\
Choice)
\end{tabular} & $\begin{array}{l}\text { teamwork } \\
\text { skills were } \\
\text { enhanced } \\
\text { (Multiple } \\
\text { Choice) }\end{array}$ \\
\hline $\begin{array}{l}\text { Chi-square } \\
\text { df } \\
\text { Asymp. Sig. }\end{array}$ & $\begin{array}{c}2.379 \\
1 \\
.123\end{array}$ & $\begin{array}{c}3.280 \\
1 \\
.070\end{array}$ & $\begin{array}{c}3.914 \\
1 \\
.048\end{array}$ & $\begin{array}{c}4.178 \\
1 \\
.041\end{array}$ \\
\hline
\end{tabular}

TABLE III

DATA FOR ON-CAMPUS AND DISTANCE STUDENTS RELATING TO PROBLEM SOLVING AND TEAMWORK SKILLS

\begin{tabular}{|c|c|c|c|c|c|c|}
\hline $\begin{array}{c}\text { On- } \\
\text { campus }\end{array}$ & 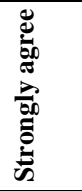 & 选 & 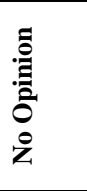 & 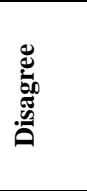 & 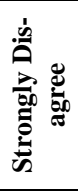 & 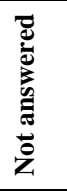 \\
\hline \multirow{2}{*}{$\begin{array}{l}\text { Problem } \\
\text { solving } \\
\text { skills were } \\
\text { enhanced }\end{array}$} & $\begin{array}{c}22 \\
(10 \%) \\
\end{array}$ & $\begin{array}{c}144 \\
(65 \%) \\
\end{array}$ & $\begin{array}{c}22 \\
(10 \%) \\
\end{array}$ & $\begin{array}{c}16 \\
(7 \%) \\
\end{array}$ & $\begin{array}{c}12 \\
(7 \%) \\
\end{array}$ & $\begin{array}{c}7 \\
(3 \%) \\
\end{array}$ \\
\hline & $\begin{array}{c}56 \\
(9 \%)\end{array}$ & $\begin{array}{c}337 \\
(57 \%)\end{array}$ & $\begin{array}{c}89 \\
(15 \%)\end{array}$ & $\begin{array}{c}70 \\
(12 \%)\end{array}$ & $\begin{array}{c}37 \\
(6 \%)\end{array}$ & $\begin{array}{c}4 \\
(1 \%)\end{array}$ \\
\hline \multirow{2}{*}{$\begin{array}{l}\text { Teamwork } \\
\text { skills were } \\
\text { enhanced }\end{array}$} & $\begin{array}{c}37 \\
(17 \%)\end{array}$ & $\begin{array}{c}140 \\
(63 \%)\end{array}$ & $\begin{array}{c}21 \\
(9 \%)\end{array}$ & $\begin{array}{c}9 \\
(4 \%)\end{array}$ & $\begin{array}{c}11 \\
(5 \%)\end{array}$ & $\begin{array}{c}5 \\
(2 \%)\end{array}$ \\
\hline & $\begin{array}{c}79 \\
(13 \%)\end{array}$ & $\begin{array}{c}355 \\
(60 \%)\end{array}$ & $\begin{array}{c}41 \\
(7 \%)\end{array}$ & $\begin{array}{c}76 \\
(13 \%)\end{array}$ & $\begin{array}{c}33 \\
(6 \%)\end{array}$ & $\begin{array}{c}5 \\
(1 \%)\end{array}$ \\
\hline
\end{tabular}

could be due to many reasons including their perception that they already had significant teamwork skills prior to the course, their dislike of teamwork (in an academic context) and difficulties in managing virtual teamwork.

Student perceptions of teamwork and their teamwork ability were tested at the end of the course using surveys, team reflections and comments from unprompted student reflections in the portfolio. For students, teamwork features as both the best and the worst aspect of the course, but there was a shift in awareness and understanding of their own skills and knowledge base. Figure 5 shows the collated response to the teamwork questions in the end of semester survey. The majority of the students believe that their teamwork skills have increased as a result of the course. The correlation between these two questions results was tested using Spearman's technique, which is suitable for ordinal data [30] and was significant at the 0.01 level. 


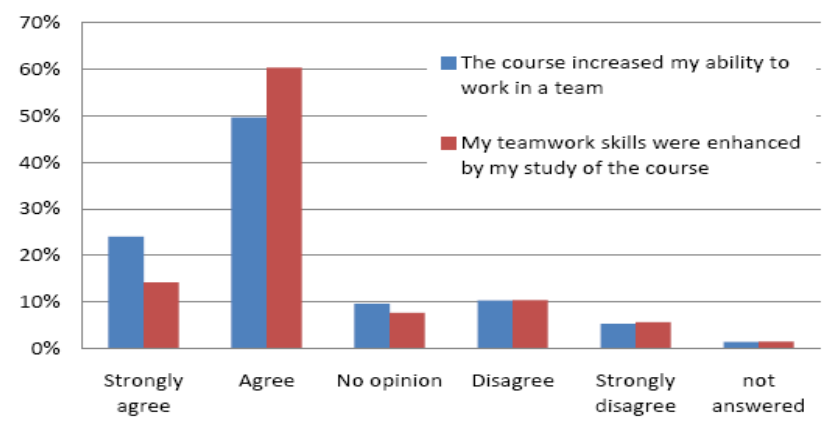

Figure 6. Student perceptions on teamwork

In course evaluation surveys, teamwork featured predominantly as a response to the best aspect of the course but there were also comments citing teamwork as the worst aspect of the course. The number of comments in response to: "the most helpful aspect of the course" which mentions teamwork far outweighed those given in response to "the least helpful aspect of the course". This validates the survey data. Similar responses were noted in the portfolios as shown by the two following examples:

....one of the assessments focused on the building of teams and how they move through different stages after being formed which $i$ [sic] found was very interesting and something that could be applied within your team. comment from portfolio

The course is a lot different to what I had imagined it to be. It's not just textbooks and teachers, but learning from experience, which is what life is going to be all about. University is not only preparing me for my career but for the world I am going to be a part of in the future. - comment from portfolio

Comparable results were seen with the other key course objectives: communication skills, problem solving skills and independent and self directed learning.

The course presents many opportunities for development and improvement of communication skills. These span:

- Formal (formal technical reports, memos and presentations) and informal (discussion forums and synchronous chat)

- Individual (portfolios and in team meetings) and team (team reports and communication with facilitators and course examiner)

The skills largely focus on written communications. Very few teams have the opportunities for teleconferencing for example. Students begin to understand the complexities of communication, particularly without the normal cues from intonation and expression.

From the surveys, $78 \%$ of the students either agreed or strongly agreed that the course had increased their communication skills.

......I feel that working externally and communicating solely via the internet, exacerbates the issues that can arise when working in a team. You have to put in extra effort to communicate effectively. i.e. correctly word your statements so that they cannot be misinterpreted. It's from this aspect of the subject that I feel I have learnt the most thus far. I am surprised at how I am actually using these communication skills in my day-to-day work now with success - comment from portfolio
Written communication is a skill that improves with practice, and this course has definitely given me a lot of practice. One of the reasons that this course teaches professional writing better than others, is the fact that it allows students to critique each other's work. Not only have I learned from having my own work critiqued, but also from critiquing the work of other students. - comment from portfolio

I also found that it was easy to communicate within a group via email and the Internet. I enjoyed this part of the course, as it allowed members to join in discussions at different times of the day and this suited the group as we all work different hours and have a range of internet access times available to us - comment from portfolio

To date there has been no thorough investigation of the improvement of communication skills in the students. Anecdotal evidence supports the assumption of improvement in writing skills in some students, but not in all. Similarly the examiners of following PBL courses indicate a difference in skill level between those students who have successfully completed the first course when compared to students who gained an exemption in the course. These students struggle not only with the concept of PBL but also communicating electronically. However this assumption has not yet been rigorously investigated.

The course allowed students to apply their prior learning, skills and experience, to a variety of scenarios. Like teamwork, many students believe they already know about 'problem solving' and have sufficient and effective skills in this area. On-campus students, particularly those with no work experience (have come straight from school) equate problem solving to solving text book problems in mathematics or physics. Older students assume problem solving skills are a consequence of experience.

"I solve problems every day at work", is a common response from students when asked about their skills.

Over the duration of the course, students believe that their problem solving skills have been enhanced. Their appreciation of how their own prior skills and knowledge, as well as those of their colleagues can be effectively utilised in problem solving has also increased. The assessment tasks encourage and support teams and individuals to reflect on and understand the steps undertaken in solving problems. Students utilise their prior knowledge and the knowledge of their colleagues not only in solving the problem, but also to meet their individual learning goals. There is a significant correlation between these three aspects and demonstrates that the wide range of entry paths, educational and work experience of the students in the course allows the sharing of knowledge and mentoring within the problem solving exercise.

\section{CONCLUSIONS}

This paper investigates the continuous development and evaluation of the first PBL course, ENG1101 Engineering Problem Solving 1. An initial investigation proved the concept of PBL delivered to students working entirely in virtual space. Subsequent reflection (by the author), literature review and implementation of new ideas resulted in a significant improvement in the key areas of problem solving, communication, teamwork and self directed learning skills.

Some areas such as communication skills require further investigation to fully detail improvements, but current 
data supports the hypothesis that improvements are successful.

The majority of students believe that their problem solving, communication, teamwork and self learning skills have increased as a result of the course. Data sources include student surveys with five point Likert scale validated by short response answers and unprompted reflections in student portfolios.

Further, in depth investigation is indicated in some areas for future work but the data to date supports the hypothesis that the course is delivering on key graduate attributes. These attributes have been identified by industry and accreditation bodies as integral to the success of future engineering graduates in a global economy.

The course successfully uses the diversity and expertise of the student cohort, fostering mentoring and peer assistance for the transference of skills and attaining self nominated learning goals. Again, the literature suggests that these learner centred approaches to education are necessary for tertiary education.

The implementation of PBL in virtual space is dependent on a number of major issues: the support of suitably trained staff, student teams forming a learning community, and the incorporation of a suitable Learning Management System into the design and implementation of the PBL curriculum. These areas are investigated and detailed in future publications.

\section{REFERENCES}

[1] Dowling, D.G. Managing student diversity in the Master of Engineering Practice program. in 20th Annual Conference for the Australasian Association for Engineering Education. 2009. University of Adelaide.

[2] Brodie, L. and M. Porter, Transitions to first year Engineering diversity as an asset. Studies in Learning, Evaluation, Innovation and Development, 2009. 6(2): p. 1-15.

[3] University of Southern Queensland. Overview of USQ. 2009 [cited 2009 10/6/09]; Available from: http://www.usq.edu.au/ aboutusq/facts.htm.

[4] Dowling, D., Designing a competency based program to facilitate the progression of experienced engineering technologists to professional engineer status. European Journal of Engineering Education, 2006. 31(1): p. 95-107. http://dx.doi.org/10.1080/ 03043790500429542

[5] Brodie, L. and M. Porter, Engaging distance and on-campus students in Problem Based Learning. European Journal of Engineering Education, 2008. 33(4): p. 433-443. http://dx.doi.org/ 10.1080/03043790802253574

[6] Perrenet, J.C., P.A. Bouhuijs, and J.G. Smits, The Suitability of Problem-based Learning for Engineering Education: theory and practice. Teaching in Higher Education, 2000. 5(3): p. 345-358. http://dx.doi.org/10.1080/713699144

[7] Norman, G.R. and H.G. Schmidt, Effectiveness of problem-based learning curricula: theory, practice and paper darts. Medical Education, 2000. 32(9): p. 721-728. http://dx.doi.org/10.1046/j.13652923.2000.00749.x

[8] Sawyer, R.K., The Cambridge Handbook of the Learning Sciences. 2006: Cambridge University Press. 627.

[9] Knowles, M., The adult learner: a neglected species. 1990, Houston: Gulf Publishing Company.

[10] Norman, G. and H. Schmidt, The psychological basis of problembased learning: a review of the evidence. Acad Med, 1992. 67: p. 557-565. http://dx.doi.org/10.1097/00001888-199209000-00002

[11] Barrows, H.S., A specific problem-based, self-directed learning method designed to teach medical problem-solving skills, and enhance knowledge retention and recall, in Tutorials in Problembased Learning. A New Direction in Teaching the Health Professions,, H.G. Schmidt and M.L. DeVolder, Editors. 1984: Maastricht, Van Gorcum. p. 16-32.
[12] O’Kelly, J., et al. Problem Based Learning: A Software Engineering Curriculum Proposal. in International Conference of Software Engineering. 2006. Department of Computer Science, NUI Maynooth, Ireland

[13] Duch, B., Models for problem Based Instruction in Undergraduate Courses, in The Power of Problem Based Learning, B. Duch, S. Groh, and D. Alien, Editors. 2001, Stylus: Sterling, Virginia.

[14] Maudsley, G., Do we all mean the same thing by 'Problem Based Learning'? A review of the concepts and a formulation of the ground rules. Acad Med, 1999. 74: p. 178-185. http://dx.doi.org/10.1097/00001888-199902000-00016

[15] Kolmos, A., Facilitating change to a problem-based model. International Journal for Academic Development, 2002. 7(1): p. 63-74. http://dx.doi.org/10.1080/13601440210156484

[16] Mills, J.E. and D.F. Treagust, Engineering Education - Is ProblemBased or Project-Based Learning the Answer? Australasian Journal of Engineering Education, 2003. online publication(20032004).

[17] Brodie, L.M., Problem Based Learning for teams working in virtual space, in Faculty of Engineering and Surveying. 2010, University of Southern Queensland: Toowoomba, QLD. p. 314.

[18] ABET (2007) Criteria For Accrediting Engineering Programs.

[19] Engineers Australia, Accreditation Management System. Vol. December 2004. 2004, Melbourne, Aust: Engineers Australia.

[20] Arnison, L. and P. Miller, Virtual teams: a virtue for the conventional team. Journal of Workplace Learning, 2002. 14(4): p. 166173. http://dx.doi.org/10.1108/13665620210427294

[21] Thoben, K. and M. Schwesig. Meeting Globally Changing Industry Needs In Engineering Education. in ASEE/SEFI/TUB Colloquium. 2002. Berlin, Germany: American Society for Engineering Education.

[22] National Academy of Engineering The Engineer of 2020: Visions of Engineering in the New Century. 2004, Washington, DC: The National Academies Press. 102.

[23] Jamieson, L., Engineering Education in a Changing World, in IEC DesignCon Conference. 2007: Santa Clara, California, USA.

[24] Anderson, T., Toward a theory of online learning, in Theory and practice of online learning., T. Anderson and F. Elloumi, Editors. 2004, Athabasca University: Athabasca, Canada. p. 33-40.

[25] Brodie, L., eProblem Based Learning - Problem Based Learning using virtual teams. European of Engineering Education, 2009. 34(6): p. 497-509. http://dx.doi.org/10.1080/03043790902943868

[26] Brodie, L. and L. Jolly. Providing Ongoing Just in Time Professional Development in Engineering Education. in 21st Annual Conference for the Australasian Association for Engineering Education. 2010. Sydney, Australia: The Faculty of Engineering \& Information Technology, University of Technology, Sydney, Sydney, NSW, Australia.

[27] Gibbings, P. and L. Brodie, Assessment Strategy for an Engineering Problem Solving Course. International Journal of Engineering Education, 2008. 24(1, Part II): p. 153-161.

[28] Brodie, L., Assessment strategy for virtual teams undertaking the EWB Challenge, in Australasian Association of Engineering Educators, L. Mann, A. Thompson, and P. Howard, Editors. 2008, CQ University: Yeppoon, QLD. p. CDROM.

[29] Brodie, L., et al. Re-skilling Staff for Teaching in a Team Context. in EE 2006 International Conference on Innovation, Good Practice and Research in Engineering Education. 2006. Liverpool, England.

[30] Siegel, S., Nonparametric Statistics. The American Statistician, 1957. 11(3): p. 13-19. http://dx.doi.org/10.2307/2685679

\section{AuTHORS}

L.M. Brodie is an Associate Professor in the Faculty of Engineering and Surveying. Her research interests include engineering education, Problem Based Learning, assessment and the first year experience. She is a board and founding member of the USQ Teaching Academy and Director of the Faculty Engineering Education Research Group. Lyn was the academic team leader for the teaching team which successfully designed a strand of PBL courses 
for the faculty. Her work has been recognised through several awards including a University Award for Design and Delivery of Teaching Materials, Carrick Institute Citation and Australian University Teaching Award for Innovation in Curricula Learning and Teaching, USQ Associate Learning and Teaching Fellowships for curriculum and assessment development and recognition from the
Australian Association of Engineering Educators for innovation in curricula.

This article is an extended version of a paper presented at the International Conference EDUCON2011, held in April 2011 at PSUT, in Amman, Jordan. Submitted, April $30^{\text {th }}$, 2011. Published as resubmitted by the authors, August $2^{\text {nd }}, 2011$ 